Anna Boguszewska

Uniwersytet Marii Curie-Skłodowskiej w Lublinie

\title{
Wybitni artyści-nauczyciele sztuki książki w Polsce
}

\section{Wprowadzenie}

Usamodzielnienie grafiki użytkowej rozwijającej się równolegle z grafiką warsztatową (chociaż nie równoprawnie) następowało powoli. Grafika użytkowa związana jest z rynkiem wydawniczym i reklamą, obejmuje projektowanie plakatu, ilustracji, czasopism i gazet, ekslibrisu i liternictwa, znaczków pocztowych i banknotów, druków okolicznościowych. Dwudziestolecie międzywojenne w Polsce to czas ścierania się poglądów dotyczących granicy między rzemiosłem artystycznym a sztuką czystą. Projektowaniu ilustracji książkowej częstokroć odmawiano miana działalności artystycznej. Uczelnie artystyczne stanowiły środowiska opiniotwórcze. Do najwybitniejszych w Polsce artystów i nauczycieli twórców nowoczesnej grafiki polskiej i sztuki książki tego okresu, którzy wznieśli tę dyscyplinę na wyżyny artyzmu, należeli: Edmund Bartłomiejczyk ${ }^{1}$, Władysław Skoczylas, Stanisław Ostoja-Chrostowski ${ }^{2}$. Należy wymienić również działania arty-

\footnotetext{
${ }^{1}$ Edmund Bartłomiejczyk, artysta grafik, nauczyciel (1885-1950), początkowo wykładał grafikę na Politechnice Warszawskiej. Od 16 października 1926 r. wykładowca grafiki użytkowej, od 1 października 1930 profesor grafiki użytkowej w Katedrze Grafiki Użytkowej, jego asystentem był Edward Manteuffel, wybitny grafik, ilustrator (od 1 października 1936 r. do 31 sierpnia 1938 r.) oraz B. Bocianowski, artysta ilustrator, (od 1 października 1938 r.). K. Piwocki, Historia Akademii Sztuk Pięknych $w$ Warszawie 1904-1964, Wrocław 1965, s. 83-85; Archiwum ASP w Warszawie, Życiorys, Akta osobowe, KD-97.

${ }^{2}$ Stanisław Ostoja-Chrostowski (1897-1947), wybitny artysta grafik. W latach 1923-1930 studiował w Szkole Sztuk Pięknych w Warszawie. Od 1929 członek Stowarzyszenia Polskich Artystów Grafików Ryt. Od 1934 członek Koła Artystów Grafików Reklamowych. W roku 1937 objął Katedrę Grafiki Artystycznej w ASP w Warszawie. Od 1945 rektor ASP w Warszawie. Zob.: M. Grońska, Stanisław Ostoja-Chrostowski 1900-1947, „Akademia Sztuk Pięknych w Warszawie. Zeszyty Naukowe”, 1986, nr 2; A. Pietrzak, S. Ostoja-Chrostowski (1900-1947) grafika, ekslibris, rysunki i matryce graficzne ze zbiorów Biblioteki Narodowej, Warszawa 2007.
} 
stów nauczycieli, jak: Witold Chomicz ${ }^{3}$, Wacław Radwan ${ }^{4}$, Bonawentura Lenart ${ }^{5}$ i Adam Półtawski ${ }^{6}$.

Dzieje kształcenia w Polsce Ludowej w zakresie grafiki książkowej związane są z postaciami kilku artystów-nauczycieli, których potencjał artystyczny i pedagogiczny ma zasadnicze umocowanie w okresie międzywojennym i którzy wnieśli wielki potencjał przedwojennego doświadczenia w kształcenie w zakresie sztuki książki. Są to: Edmund Bartłomiejczyk, Stanisław Ostoja-Chrostowski, Witold Chomicz, Wacław Radwan. Wymienionym artystom przypadła rola wznawiania kształcenia w zakresie grafiki książki w Polsce po drugiej wojnie światowej.

${ }^{3}$ Witold Chomicz (1910-1984), polski malarz, grafik, nauczyciel, jego zainteresowania twórcze dotyczyły sztuki książki, wykładowca w Państwowym Instytucie Sztuk Plastycznych i ASP w Krakowie.

${ }^{4}$ Wacław Teofil Radwan (1887-1962), artysta grafik, typograf, ilustrator, malarz, szczególnie interesował się grafiką książkową i projektowaniem wnętrz. Wykształcenie plastyczne zdobywał w Warszawie pod kierunkiem Konrada Krzyżanowskiego, F. Ruszczyca, Wincentego Trojanowskiego, Xawerego Dunikowskiego, Jana Gałęziowskiego. Od 1921 r. związał się ze szkolnictwem artystycznym Warszawy (MSSZiM, lata 1931-1937 oraz Państwowy Instytut Robót Ręcznych). Otrzymał wiele nagród i wyróżnień artystycznych, m.in.: nagrodę za projekt mebli dla firmy „Bracia Jabłkowscy”(1919), złoty medal na wystawie w Paryżu (1925), dyplom honorowy PWK (1928), II nagrodę za projekt wnętrz gmachu Ministerstwa WRiOP (1928). W grudniu 1938 r. wszedł w skład Zarządu Głównego nowo powstałej Rady Naczelnej Centralnego Komitetu do spraw Plastyki w Polsce jako odpowiedzialny za sprawy szkolnictwa artystycznego, również w rym roku otrzymał Złoty Krzyż Zasługi za działalność artystyczną. Podczas okupacji niemieckiej był aktywny zawodowo, zaangażowany w konspiracyjne nauczanie oraz inną konspiracyjną działalność. Brał udział w powstaniu warszawskim, używał pseudonimu „Profesor”. Po wyzwoleniu wrócił do pracy zawodowej w szkolnictwie artystycznym. Największy zbiór prac graficznych artysty posiada Biblioteka Narodowa w Warszawie. Archiwum ASP w Warszawie, Życiorys z dn. 5 grudnia 1947 roku, Akta osobowe, K 511; Akta personalne Rowida, IS PAN Warszawa; Zob.: M. Zakrzewska, Radwan Wacław Teofil, Polski Słownik Biograficzny, t. XXX/1, 1987, z. 124, s. 12-14.

${ }^{5}$ Bonawentura Lenart (1881-1973), wybitny introligator, grafik, artysta książki i nauczyciel. Pierwszy w Polsce artysta, który problemy estetyki książki ujął w szerokim zakresie obejmującym grafikę książki, typografię, oprawę i konserwacje książki. Wybitny introligator, traktujący sztukę książki jako całość zestawionych elementów papieru, czcionki, druku, ilustracji i oprawy. Autor licznych teoretycznych opracowań oraz praktycznych realizacji opraw artystycznych, ekslibrisów, wyklejek. Laureat wielu prestiżowych nagród w Europie i w Polsce. Wybitny pedagog okresu międzywojennego działający w Krakowie, Wilnie i Warszawie. W 1929 założył w Bibliotece Narodowej Pracownię Konserwatorską. W latach 1929-1939 konserwator Biblioteki Narodowej. W 1936 utworzył Biuro Introligatorskie. Od 1951 r. był profesorem ASP w Warszawie i kierownikiem pracowni Konserwacji Zabytków mieszczącej się w „Zachęcie”. Zorganizował na nowo w Warszawie Pracownię Konserwacji Zabytków Grafiki. Przeszło pięćdziesiąt lat pracy artystycznej, pedagogicznej i konserwatorskiej prowadzonej na najwyższym poziomie stawia artystę na wyżynach artystycznego rzemiosła i sztuki książki w Polsce i Europie. Zob.: A. Olszewski, Bonawentura Lenart, „Projekt” 1957, nr 5.

${ }^{6}$ Adam Półtawski (15 maja 1881 - 19 września 1952), wybitny polski grafik i typograf. Jest autorem kroju pisma Antykwa Polska oraz projektu Mediewal Polski. Zob.: S. Wojciechowski, Adam Półtawski, [w:] I. Treichel (red.), Słownik pracowników ksiażki polskiej, Warszawa-Łódź 1972, s. 711-712. 
Kształcenie w zakresie formy książki w Polsce Ludowej nierozerwalnie związane jest z sylwetkami artystów profesorów wykładających w Warszawie: Janem Marcinem Szancerem i Januszem Stannym. Warto przypomnieć nauczycielskie zasługi artystów.

\section{Mistrzowie artyści-nauczyciele sztuki książki}

Akademia Sztuk Pięknych w Warszawie i Krakowie to główne ośrodki kształcenia graficznego w Polsce po drugiej wojnie światowej. Grafika użytkowa jako jedna $\mathrm{z}$ dziedzin rozwijała się stopniowo, stymulowana zakresem potrzeb rozwijającej się państwowości Polski Ludowej. Początki powojennej działalności ASP były wyjątkowo trudne nie tylko ze względu na brak jednolitej koncepcji rozwoju szkoły, ale również ze względu na dotkliwe braki kadrowe i materialne ${ }^{7}$.

W warszawskiej uczelni artystycznej po wojnie kontynuatorem zapoczątkowanego dzieła krzewienia kultury książki był również Wacław Radwan ${ }^{8}$. To artysta w pełni twórczo ukształtowany przed wojną. Przeniósł również do zorganizowanej na nowo uczelni swoje doświadczenia pedagogiczne w zakresie grafiki książki. Przez studentów grafiki doceniany był jego perfekcyjny warsztat literniczy i umiejętności typograficzne, wiązanie tekstu z ilustracją w klasycznym kanonie jedności druku i ilustracji. Upra-

${ }^{7}$ W 1947 r. umiera S. Ostoja-Chrostowski, pieczołowicie zabiegający o jej powrót do rozkwitu, w szczególny sposób dbający o rozwój grafiki artystycznej i równouprawnienie grafiki użytkowej. Jak podkreślano: „Rezultatem jego trudu było utworzenie pierwszego w Polsce wydziału grafiki”. Z mowy pogrzebowej E. Bartomiejczyka, Rękopisy mów pogrzebowych w zbiorach biblioteki narodowej, rps. IV, 10313, [za:] M. Grońska, Stanisław Ostoja-Chrostowski, 1900-1947, „Akademia Sztuk Pięknych w Warszawie. Zeszyty Naukowe” 1986, nr 2, s. 51. We wrześniu 1950 r. zmarł E. Bartłomiejczyk, powojenny dziekan Wydziału Grafiki. Funkcję dziekana Wydziału Grafiki ASP Bartłomiejczyk pełnił od 4 grudnia 1945 r. do 14 czerwca 1946 r. Archiwum ASP Warszawa. Straty te bardzo znacząco uszczupliły grono artystów grafików, którzy poprzez autorską twórczość i pracą pedagogiczną, ogromne doświadczenie w kształtowaniu przyszłych artystów oddziaływali na młodzież pragnącą kształcić się w zakresie użytkowych form graficznych. Ich twórczość w dziedzinie książki była zawsze obecna i na najwyższym poziomie. Wraz z odejściem tych artystów nauczycieli zamyka się niejako przedwojenny etap w zakresie programowym kształcenia graficznego o charakterze użytkowym na ASP.

${ }^{8}$ Wacław Teofil Radwan (6 lutego 1887 - 30 czerwca 1962), artysta grafik, typograf, ilustrator, malarz, nauczyciel, szczególnie interesował się grafiką książkową i projektowaniem wnętrz. Od 1921 r. związał się ze szkolnictwem artystycznym Warszawy (MSSZiM lata 1931-1937; Państwowy Instytut Robót Ręcznych). Laureat wielu nagród i wyróżnień artystycznych (Paryż 1925, Poznań 1928; Złoty Krzyż Zasługi za działalność artystyczną 1938). Podczas okupacji niemieckiej aktywny zawodowo, zaangażowany w konspiracyjne nauczanie. Po wyzwoleniu wrócił do pracy zawodowej w szkolnictwie artystycznym. Nagrodzony w 1954 r. za pracę pedagogiczną, otrzymał Krzyż Kawalerski Orderu Odrodzenia Polski. Największy zbiór prac graficznych artysty posiada Biblioteka Narodowa. Akta osobowe, K 511; Akta personalne W. Rowida, IS PAN. Zob.: M. Zakrzewska, Radwan Wacław Teofil, Polski Słownik Biograficzny, t. XXX/1, 1987, z. 124, s. 12-14. 
wiał głównie drzeworyt. Od 1949 roku tworzył cykle ilustracyjne do klasyki polskiej literatury (Gody życia A. Dygasińskiego, Pan Tadeusz Mickiewicza, Stara baśń Kraszewskiego, Promethidion Norwida, Pamiętniki J. Ch. Paska). W 1950 roku wydał tekę Widoki Sandomierza $w$ drzeworytach przygotowywane od 1949 roku9. Radwan tworzył również dla dzieci, znane jest jego przedwojenne opracowanie baśni Marysina służba ${ }^{10}$. W latach pięćdziesiątych jego stan zdrowia pogarszał się, nie najlepiej również czuł się w nowej rzeczywistości ideologicznej uczelni. Stopniowo wycofał się z pracy zawodowej, aby ją opuścić ostatecznie w 1962 roku.

Następcą W. Radwana - wybitnego nauczyciela - był Jan Marcin Szancer. To artysta malarz, rysownik i scenograf, który poprzez swój wielki autorytet zyskał miano człowieka-instytucji. Podniósł po raz pierwszy kształcenie w zakresie ilustracji książki do istotnej, wysokiej rangi, równorzędnej innym, użytkowym formom plastycznym ${ }^{11}$. Poprzez oddziaływanie artystyczne, metodyczne i wychowawcze w prowadzonej pracowni książki był pośrednim twórcą rozkwitu ilustracji jako dziedziny graficznej w Polsce

\footnotetext{
${ }^{9}$ A. Pietrzak, Prace graficzne profesorów studentów warszawskiej ASP w zbiorach Biblioteki Narodowej, „Biuletyn Informacyjny Biblioteki Narodowej” 2004, nr 3, s. 16.

${ }^{10}$ E. Szelburg-Ostrowska, Marysina służba, Wydawnictwo dwutygodnika dla dzieci i młodzieży „Płomyk”, Warszawa 1923.

${ }^{11}$ Jan Marcin Szancer (12 listopada1902 w Krakowie - 21 marca 1973 w Warszawie), syn Edwarda Szancera [Schanzera] i Stanisławy z Pierackich. Mimo przeciwności zdecydował o profilu swych studiów w krakowskiej Akademii Sztuk Pięknych, studiując pod kierunkiem Teodora Axentowicza, Władysława Jarockiego, Józefa Mehoffera, Ignacego Pieńkowskiego. Ukończył je z wynikiem bardzo dobrym. Nagrodę stanowiła własna pracownia malarska. Gdy miał 27 lat, Xawery Dunikowski, nauczyciel i przyjaciel, przepowiedział mu karierę ilustratora, o której początkowo artysta nie chciał słuchać. Pragnął malować freski, chciał też zostać aktorem. Ilustratorstwo niejako samo wybrało Szancera. Najstarsza ze zilustrowanych przez niego książek to czytanka polska dla uczniów II klasy szkół powszechnych Nasze miasto, wydana we Lwowie w roku 1935. Przed 1939 r. przeniósł się do Warszawy. Malował i rysował uliczki Powiśla, napisał i zilustrował kilka opowiadań. Z dużym powodzeniem próbował sił jako scenograf. Otrzymał zamówienie na projekty kostiumów do filmu Nad Niemnem, którego realizację zniweczył wybuch wojny. Był kierownikiem artystycznym i twórcą wielu ilustracji i okładek pisma dla dzieci "Świerszczyk” wznowionego 1 maja 1945 r. Od tego czasu ilustrował coraz więcej książek dla dzieci. Sygnatura jms pojawiła się po raz pierwszy w 1944 w książce Koziołeczek. Odtąd była stale obecna na wszystkich jego rysunkach. Projektował plakaty, ekslibrisy, małe formy akcydensowe, pocztówki. $Z$ wielką pasją zajmował się projektowaniem scenografii dla teatru i filmu. Był kierownikiem Doświadczalnego Ośrodka Telewizyjnego, być może zainspirowała to zainteresowanie ilustrowana w 1936 r. książka Telewizja, czyli jak człowiek nauczył się widzieć na odległość. Jan Szancer pisał również bajki i felietony. Zaistniał jako scenarzysta i reżyser w filmie Teatr mój widzę ogromny już w roku 1946. Zajmował się też tworzeniem scenografii teatralnych i filmowych. W latach 1965-1966 sprawował funkcję naczelnego scenografa w Teatrze Wielkim. Piastował funkcję prezesa warszawskiego Związku Artystów Plastyków. Pełnił również funkcję radnego w zarządzie miasta, zasiadał w Państwowej Radzie Kultury. Zob.: J. M. Szancer, Curriculum vitae, Czytelnik, Warszawa 1969; Archiwum ASP W Warszawie, Teczka osobowa, sygn. KD 148; Akta personalne Szancera, IS PAN.
} 
oraz sukcesów polskiej ilustracji na arenie międzynarodowej. Sposób pracy dydaktycznej Szancera zaowocował wieloma wybitnymi osobowościami twórczymi. Głównym motywem jego pedagogicznej pracy była nauka dotycząca związków zachodzących między obrazem a typografią oraz odpowiedniej korespondencji ilustracji z tekstem ${ }^{12}$. Mistrz bardzo musiał szanować indywidualne predyspozycje i interpretacje swoich studentów, pozostawiać swobodę w tworzeniu, skoro mogło zaistnieć wielkie zróżnicowanie w obrębie formy ilustracji, jakie prezentowali w realizacjach ilustratorskich jego uczniowie. Jak sam twierdził: ,zawsze zachęcałem studentów do czytania, do myślenia, do poznawania literatury"13.

Szancer przez kilkanaście lat sprawował obowiązki naczelnego redaktora Wydawnictwa „Ruch”. Będąc animatorem wydawanych tam książek, budował korzystnie współpracę wydawnictwa ze studentami i absolwentami ASP w Warszawie. Zdarzało się, że studenci inspirowani przez swego nauczyciela, debiutowali jeszcze podczas studiów w Pracowni Książki i Ilustracji. Jest on autorem ilustracji do ponad 240 książek, głównie literatury dla dzieci. Artysta nie unikał jednakże literatury dla młodzieży i dorosłych $^{14}$.

Olga Siemaszko współpracująca z Szancerem w redakcji czasopisma dla dzieci „Świerszczyk” wspominała szerokie zainteresowania Szancera ilustracją, teatrem, filmem: „Szancer był bardzo szybki, nigdy nie miał czasu, interesowały go różne sprawy"15. Od 31 sierpnia 1966 roku oprócz prac scenograficznych prowadził prace reżyserskie w Teatrze Wielkim w Warszawie $^{16}$. Nie jest możliwe do ustalenia, czy wielokrotne doświadczenia zdobyte w teatrze i studiu telewizyjnym wpływały na prace filmowe, ilustracyjne czy odwrotnie. Przenikanie się tych dyscyplin jest obecne już we wcześniejszej twórczości artysty. W Akademii Pana Kleksa zbudowany tam typ tytułowego bohatera, ożywiony następnie w filmie, był zarazem autoportretem artysty. Do najważniejszych realizacji należą na pewno ilustracje do Baśni Andersena ${ }^{17}$. W sposób niezwykły wykreowane postacie długo stanowiły

${ }^{12}$ Por.: S. Bołdok, J. M. Szancer, „Przegląd Artystyczny” 1966, nr 4, s. 50-52.

${ }^{13}$ Jan Marcin Szancer (1902-1973), 100-lecie urodzin, wstęp A. Matynia, Warszawa 2002.

${ }^{14}$ Dla młodzieży i dorosłych zilustrował Bajki i Satyry I. Krasickiego, Pana Tadeusza Mickiewicza, Trylogię Sienkiewicza, Faraona Prusa, książki Amicisa, Carlo Collodiego, Cervantesa, Haška, Puszkina, Swifta, Twaina, Wasilewskiej i innych. Zob.: J. M. Szancer, Teatr cudów, Czytelnik, Warszawa 1972.

${ }^{15}$ J. Rey, Nie umiem pisać. Rozmowa z O. Siemaszko, „Rzeczpospolita”, 5 lipca 1989, nr 155.

${ }^{16}$ Archiwum ASP w Warszawie, teczka osobowa Szancera, sygn. KD 148.

${ }^{17}$ Nagrodzone w Lipsku srebrnym medalem w roku 1959. 
wzorzec i obowiązujące odniesienie wizualne zarówno dla młodego jak i dorosłego czytelnika. Magia stworzonych przez niego typów i scenograficznych odniesień przemawiała do wyobraźni i była chętnie przyjmowana przez odbiorcę. Niosła koloryt i nastrój baśni, tajemnicy. Łatwo zapamiętywana, szybko wpisywała się w katalog plastycznych interpretacji tekstu.

Typowością ilustracji Szancera było ich bogactwo narracyjne, bogactwo fabuły tworzące klimat baśniowości. Atmosferę tę tworzył niewątpliwie specyficzny dla mistrza dobór środków formalnych: kreska biegłego rysownika zestawiana z malarskością plam barwnych o szerokiej gamie natężeń w obrębie jednej jakości barwnej, a także szkicowość przedstawień, zarówno rysunkowych jak i malarskich. W tonacjach szancerowskich ilustracji nie brakuje złamanych zestawień kolorystycznych, często podkreślanych kontrastem czystych czerwieni, akcentów mocnych i ważnych kompozycyjnie. Tak oznaczone punkty kulminacyjne zbierające w sobie napięcia układu form wraz z obfitością niuansów kolorystycznych tworzą to, co zwykle nazywa się nastrojowością czy klimatem przedstawienia wizualnego. Szancer stworzył swoisty typ przedstawiania postaci, zmieniając proporcje ciała, stosując ich wydłużenia, opracowując ich ruch - przywodził na myśl stylistykę teatru. Stanowiło to indywidualną cechę twórcy. Inne słynne tytuły zilustrowane przez artystę to: O Janku, co psom szył buty, Pinokio, Pan kotek był chory, O krasnoludkach i sierotce Marysi, Brzechwa dzieciom, Lokomotywa, Rzepka, Ptasie radio, Dziadek do orzechów i wiele innych.

O ilustracjach Szancera, również dzięki jego silnej osobowości i wpływom, wypowiada się ówczesna krytyka artystyczna, traktując je na równi z innymi dziedzinami grafiki użytkowej:

Ilustracje Szancera bogate w fabułę i narrację wciągają widza w rozgrywającą się fikcję literacką, a ponieważ przeznaczone są przede wszystkim dla dzieci, panuje w nich atmosfera baśniowa. Klimat ten osiąga autor przez kaligraficzną stylizację kreski, elegancję i swoisty wdzięk, powołanych do życia na kartach książki postaci - Pinokia, księżniczek, krasnali, personifikowanych roślin i zwierząt. Traktowani przez artystę ciepło, z dozą humoru, baśniowi bohaterowie zapełniają scenę, czasem się kłębią na niej w nadmiarze, ale zawsze poszerzają oddziaływanie tekstu literackiego, kształtując wizualnie typ bohatera w umyśle dziecka. Zastanawiający jest fakt, że twórczość adresowana do kilkuletnich malców znajduje tylu wyznawców wśród dorosłych ${ }^{18}$.

W setną rocznicę urodzin artysty okazało się, że jego ilustracje mają ciągle dużą żywotność. Odkrywana jest istota aktualności:

${ }^{18}$ S. Bołdok, J. M. Szancer, s. 50. 
W swoich ilustracjach Szancer teatralizuje gesty, mimikę, nadaje scenom dramatyczny rozmach, finezyjnie rozbudowuje przestrzeń. To powoduje, że do ilustracji Szancera można powracać wielokrotnie, za każdym razem odnajdując nowe szczegóły. [...] Szancer doskonale znał psychologię odbioru, stąd z całą świadomością tworzył wyrazistych bohaterów, do których widz chciał się przywiązać. [...] Przeważnie ilustrował książki dla dzieci, ale nie zamierzał z tego powodu upraszczać formy. Wiedział, że „dziecko nie chce patrzeć na rysunki, które samo potrafi zrobić"19.

Funkcję kierownika Pracowni Książki i Ilustracji w warszawskiej ASP Szancer sprawował do 1969 roku, kiedy to w związku z pogorszeniem stanu zdrowia wystąpił o przejście na emeryturę. Z racji zainteresowania i kształtowania procesu dydaktycznego dotyczącego tajników sztuki książki niewątpliwie wybitna rola przypada godnemu następcy Januszowi Stannemu ${ }^{20}$. Miał duże zasługi w zakresie kształcenia artystów plastyków, dla których projektowanie ilustracji książkowej oraz widzenie książki jako formalnej całości stanowić będzie istotę twórczej działalności. Janusz Stanny pracował w latach 1960-1971 jako asystent Jana Marcina Szancera, w 1971 roku objął stanowisko kierownika katedry. W 1986 roku uzyskał tytuł profesora. Sprawował nadzór nad kształceniem młodych ilustratorów, projektantów książki do 2004 roku $^{21}$.

Praca pedagogiczna tego twórcy stanowiła istotną część jego działalności na rzecz upowszechniania wysokiego poziomu graficznego książki, rozumianej jako nośnik kultury plastycznej. „Dla mnie - wypowiada się artysta - ilustracja jest tłumaczeniem literatury na inny język, tak jak tłumaczy się na wszystkie języki świata, tu przekłada się na obraz, kolor, kompozycję, dramaturgię"22. W swym sposobie pracy pedagogicznej nawiązuje do doświadczeń wyniesionych ze studiów pod kierunkiem malarza Józefa Czajkowskiego i grafika plakacisty Henryka Tomaszewskiego. Od Józefa Czajkowskiego, jak twierdzi Stanny, przeniósł optymistyczny sposób po-

${ }^{19}$ Jan Marcin Szancer (1902-1973)...

${ }^{20}$ Janusz Stanny urodził się 29 lutego 1932 r. w Warszawie. W latach 1952-1957 studiował na warszawskiej ASP na Wydziale Grafiki. Dyplom uzyskał w pracowni profesora Henryka Tomaszewskiego. Współpracował z wydawnictwami Nasza Księgarnia, PIW, Czytelnik, Iskry, Ruch oraz czasopismami dla dzieci, takimi jak „Miś”, „Świerszczyk” i „Płomyczek”. W latach 1960-1975 kierował wydawnictwem Ruch. Zajmuje się rysunkiem satyrycznym („Gazeta Wyborcza”, „Przegląd”, „Szpilki”), grafiką projektową, książkową, plakatem i grafiką filmu animowanego. Zob.: Janusz Stanny, Galeria Pod Podłoga, Lublin 2002.

${ }^{21}$ Zob.: K. Iwanicka, Wplyw warszawskiej Akademii Sztuk Pięknych na kształtowanie się polskiej szkoly ilustracji ,Guliwer” 1993, nr 4.

${ }^{22}$ Przymus szopa pracza. Z prof. Januszem Stannym rozmawia Katarzyna Kotowska, „Guliwer” 2004, nr 2, s. 47. 
strzegania świata oraz „bardzo ostre wymagania warsztatowe” wyrażające się w gruntownej znajomości rysunku aż do biegłości, która nie krępowałaby realizacji pomysłu. Wspominając Tomaszewskiego, mówi:

na wyższych latach Akademii najsilniejsze wrażenie wywarł na mnie blisko 40 lat młodszy od Czajkowskiego Henryk Tomaszewski, w którego pracowni plakatu panowała niepowtarzalna atmosfera myślowego fermentu. Konstruowane przezeń zadania, zaskakujące, zadziorne jakby, prowokujące do przyjęcia intelektualnej postawy wobec realizacji wówczas mogły uchodzić za najśmielszy eksperyment, dziś owiany legendą ${ }^{23}$.

W pracy ilustratorskiej Stanny stosuje rysunek o swobodnej, często miękkiej kresce konturowej lub finezyjne, wręcz koronkowe nawarstwienie linii tworzących fakturę, walor, wydobywające na karty papieru iluzję przestrzeni. Kompozycje te są pełne humoru lub liryzmu. W kompozycjach barwnych artysta tworzy niezwykłe, czasem surrealistyczne przedstawienia pełne napięć nastroju. Jak podpowiada Wróblewska:

Stanny jest za precyzją i myśleniem, za integracją czcionki i litery z obrazem. Scalająco w stosunku do wszystkich używanych przez niego elementów w ilustracji i sposobów graficznych działa rysunek, który zamyka kompozycję strony w zwartym kształcie. [...] Typografia staje się wtedy elementem gry plastycznej a plastyka - częścią słowa literackiego ${ }^{24}$.

Janusz Stanny zilustrował ponad 200 książek. Szerokie zainteresowania twórcze artysty najpełniej wyraziły się w twórczości dla dzieci, a docenione zostały wieloma nagrodami. Pierwsza publikacja Janusza Stannego adresowana do młodego odbiorcy to wydany w 1957 roku Magik Jana Brzechwy ${ }^{25}$. Janusz Stanny jest prekursorem twórczości w zakresie książek autorskich. Jego Koń i kot, O malarzu rudym jak cegła, wydane w 1961 roku przez wydawnictwo Ruch oraz Baśń o królu Dardanelu, wydana w 1963 roku przez Naszą Księgarnię, są przykładem znakomitej integracji obrazu i słowa, artystycznej możliwości szczególnego twórczego przemawiania do dzieci, do dziś w Polsce niedocenianego. Ilustracje w Zaczarowanym krawcu to autorski sposób opracowania liternictwa oraz eksperymentalny sposób malowania gumową gruszką napełnioną farbą umożliwiającą uzyskanie płynnego konturu, wymagającego mistrzowskiej precyzji i zwinności ruchów przy malowaniu. We wspomnieniach artysta mówi, że z perspektywy czasu trudności poligraficzne nie stanowią już problemu przeszkadzającego

\footnotetext{
${ }^{23}$ Janusz Stanny rozmawia z redakcja, rozmawiał J. Zielecki, „Sztuka” 1989, nr 2.

${ }^{24}$ D. Wróblewska, Janusz Stanny, „Projekt” 1968, nr 6, s. 14.

${ }^{25}$ Stanny, Warszawa 2002.
} 
w percepcji książki, że ilustracje gorzej wyglądałyby na lśniącym współcześnie papierze, czyli wskazuje nam prawdziwą wartość kunsztu rysownika i koncepcji książek ${ }^{26}$. Najważniejsze jego publikacje ilustracji dla dzieci zawarte są m.in. w książce J. Brzechwy Pchła Szachrajka wydanej w 1996 roku przez Świat Książki, wpisanej ze względu na ilustracje na Międzynarodową Listę Honorową IBBY w 1998 roku. To sukces wyjątkowy. Artysta brał udział w wielu wystawach krajowych i zagranicznych. Wystawy indywidualne odbyły się w Lublinie, Poznaniu, Pradze, Paryżu, Sierre (Szwajcaria), Warszawie. Udział w wystawach zbiorowych w Bratysławie, Belgradzie, Bolonii, Lipsku, Londynie, Moskwie, Tokio, Kairze, Wiedniu dotyczy najważniejszych miejsc wystawowych świata z zakresu ilustracji.

Janusz Stanny należy do pokolenia artystów, dla których ilustracja książkowa jest dziedziną eksperymentalną i twórczą. Podkreśla, że zawsze chce widzieć w otaczającej rzeczywistości tę lepszą, a często umykającą stronę życia, dostrzega śmieszność sytuacji przekładającą się na twórczość również w ilustracji. Artysta ma w swej karierze ilustracje do klasyki literatury polskiej i europejskiej (Biblia, Boska Komedia Dantego, Lis Przechera J. W. Goethego ${ }^{27}$, Bajki La Fontaine'a, Pan Tadeusz A. Mickiewicza, Don Kichot M. Cervantesa ${ }^{28}$, Przygody Sindbada Żeglarza B. Leśmiana ${ }^{29}$, Baśnie J. Ch. Andersena ${ }^{30}$ oraz wiele utworów dla dzieci, m.in. J. Brzechwy, H. Januszewskiej W. Broniewskiego i W. Chotomskiej), dlatego sam określa się jako artysta spełniony ${ }^{31}$. Spotkania ze Stannym, te bezpośrednie i poprzez jego dzieła urzekają humorem, skrótem myślowym, liryką, trafnością i mądrością puenty. Ilustracje Stannego weszły do kanonu klasyki ilustracji polskiej o najwyższym poziomie artystycznym. Jak artysta sam przyznaje, lubi robić ilustracje do literatury, która przemawia obrazem. Artysta ma na swym koncie wiele nagród i wyróżnień. Najcenniejsze to: druga nagroda w konkursie w Buenos Aires w 1966 roku (Don Kichot M. Cervantes), Premio Grafico na Międzynarodowych Targach Książki w Bolonii w 1968 roku (Zaczarowany krawiec H. Januszewskiej), Złoty Medal IBA w Lipsku

\footnotetext{
${ }^{26}$ Przymus szopa pracza..., s. 51.

${ }^{27}$ Wyróżnienie w konkursie PTWK Najpiękniejsza Ksią̇ka Roku w roku 1990.

${ }^{28}$ Druga nagroda w konkursie Buenos Aires w roku 1966.

${ }^{29}$ Pierwsza nagroda w konkursie PTWK Najpiękniejsza Książka Roku w roku w 1965; złoty Medal IBA w Lipsku w roku 1971.

${ }^{30}$ Medal BIB w Bratysławie w $1977 \mathrm{r}$.

${ }^{31}$ Wernisaż 26 marca 2007, Wystawa w 50-lecie pracy twórczej, pod honorowym patronatem Ministra Kultury i Dziedzictwa Narodowego Kazimierza Michała Ujazdowskiego, Muzeum Karykatury w Warszawie.
} 
w 1971 roku (Przygody Sindbada Żeglarza B. Leśmiana, Czytelnik 1965), srebrny medal na targach książki w Moskwie w 1971 roku (książka autorska, Baśń o królu Dardanelu, Nasza Księgarnia 1963), Medal BIB w Bratysławie w 1975 roku oraz Premio Europeo w Padwie w 1976 roku (Lwy H. Januszewskiej, Ruch 1974), Medal BIB w Bratysławie w 1977 roku (Baśnie J. Ch. Andersena, PIW 1975). W kraju artysta był nagradzany (1965, 1968, 1971, 1975, 1980) i wyróżniany $(1990,1996)$ w konkursie Polskiego Towarzystwa Wydawców Książek (PTWK) „Najpiękniejsza Książka Roku” w Warszawie ${ }^{32}$. W 1987 i 1999 roku został nagrodzony za wybitne osiągnięcia artystyczne i całokształt twórczości ilustratorskiej nagrodą PTWK oraz w 2000 roku nagrodą Ministra Kultury i Dziedzictwa Narodowego za rok $2000^{33}$. Nagrodzenie artysty medalem Polskiej Sekcji IBBY stanowi wyraz najwyższego uznania środowiska twórców. Artysta prezentował swoją twórczość w bardzo licznych wystawach w kraju i za granicą, zyskując wielką popularność. Ilustracja książkowa jest ważną, ale nie jedyną sferą twórczości Stannego. Zajmował się też grafiką projektową, plakatem, rysunkiem, filmem animowanym i ilustracją prasową ${ }^{34}$.

W kształtowaniu osobowości twórczych wielu artystów ilustratorów ważną rolę w środowisku warszawskim spełnił Henryk Tomaszewski. Jego uczniowie, obok plakatu, grafiki projektowej, z powodzeniem zajmują się ilustracją. Sam mistrz wprowadził do jej stylistyki uproszczenie znaku plastycznego, dyscyplinę koloru, wytyczając na nowo drogę podjętą przez polskich artystów ilustratorów pod koniec lat trzydziestych XX wieku. W gronie artystów związanych pracą nauczycielską z warszawską ASP, w których twórczości znajdujemy epizody ilustratorskie adresowane do dzieci, znajduje się Bogdan Bocianowski, Michał Bylina, Józef Czerwiński, Andrzej Jurkiewicz, Józef Mroszczak, Roman Owidzki, Konstanty M. Sopoćko, Wojciech Zamecznik.

${ }^{32}$ Stanny, katalog, Warszawa 2002; K. Iwanicka, Ludzie polskiej książki, „Wydawca” 2002, nr 5, s. 42-43; Budować wrażliwość. Z Januszem Stannym rozmawia Hanna Gancarczyk, „Guliwer” 1994, nr 1, s. 13-15.

${ }^{33}$ K. Iwanicka, Nagroda dla Janusza Stannego, „Guliwer” 2001, nr 2, s. 79-80; Z. Januszewski, Stuszna racja, Warszawa 2002; Janusz Stanny, Galeria ZPAP, Lublin 2002.

${ }^{34}$ Filmy dla dzieci, rysunkowe, barwne, najczęściej bez dialogów: Wędrówka pędzla i ołówka (1971), Opowieść o porcelanowym czajniczku (1973), O biednym Achmedzie, jego nadobnej córce Zubeidzie i zakochanym Dżinie (1978), Jak Jano słońce sprowadził (1987) oraz filmy adresowane do młodzieży i dorosłych: Vendetta (1966), Papieros (1967), Przeciwnik (1968), Mini (1969), Pan wie, kim ja jestem (1970), Och! och! (1970), serial Profesor Filutek. 
W krakowskiej w ASP ważną postacią po wojnie w zakresie kształcenia grafiki użytkowej był Witold Chomicz ${ }^{35}$. W latach powojennych istotne działania podejmowali Jerzy Karolak i Andrzej Jurkiewicz, potem związani ze środowiskiem warszawskim.

Witold Chomicz sprawował funkcję kierownika Katedry Grafiki Książki w ASP w Krakowie, był oddanym studentom pedagogiem. Jego powojenne sposoby nauczania stanowiły przełożenie doświadczenia pedagogicznego zdobywanego przed drugą wojną. Obejmowały podobne zadania do realizacji, mające na celu uzyskanie biegłości warsztatowej oraz poznania klasycznych podstaw projektowania książki. Twórcza osobowość Chomicza charakteryzuje się wysmakowanym zdobnictwem, stosowanym z umiarem. Sztukę książki opierał na regułach typografii, który pragnął zaszczepić u swoich wychowanków. Podobną rolę spełniało zafascynowanie rodzimym folklorem oraz krakowskim, bardzo bogatym dziedzictwem w zakresie sztuki książki. Był przyjacielem domu Witkiewiczów, jego przyjaźń z wybitnym znawcą pięknej książki Kazimierzem Witkiewiczem owocowała również w pracy pedagogicznej. Jedną z jego pasji było bibliofilstwo. Zapewne dlatego Katedrę Grafiki Książki studenci mianowali Oficyną Białego Kruka. Staraniem Chomicza zachowany został w pracowni warsztat typograficzny pamiętający czasy Muzeum Przemysłowego. Jego pietyzm dla przeszłości nie zamykał jednak dróg do nowych rozwiązań formalnych w książce. Zainteresowanie pracownią książki wśród studentów grafiki było bardzo duże dzięki bogatej artystycznie i przyjaznej studentowi osobowości prowadzącego.

Witold Chomicz był twórcą aktywnym. Tworzył w dziedzinie grafiki, głównie drzeworyty i autolitografie oraz witraże $\mathrm{e}^{36}$. Opracował graficznie

\footnotetext{
${ }^{35}$ Witold Chomicz, malarz i grafik (1 listopada 1910 - 15 marca 1984). Dzieciństwo spędził w Kijowie, był synem Leonarda Chomicza i Ewy Święckiej. Do szkoły średniej uczęszczał w Lublinie (absolwent II Liceum Ogólnokształcącego im. hetmana Jana Zamoyskiego w Lublinie), następnie kształcił się w Krakowie i Pradze. Od 1934 r. pracował w krakowskim szkolnictwie artystycznym, interesując się sztuką książki. Zainspirowany sztuką ludową, był wielkim miłośnikiem i znawcą folkloru krakowskiego. Wielokrotnie sprawował funkcje jurora konkursu krakowskich szopek. Malował obrazy olejne, tworzył drzeworyty, plakaty i projekty witraży.

${ }^{36}$ Witold Chomicz - malarstwo, rysunek, grafika, 1923-1972, oprac. graf. W. Chomicz, J. Szczurek, Tarnów 1972; E. Rutkowiak, Witold Chomicz jako grafik książki, „Biuletyn Biblioteki Jagiellońskiej" 1995 , nr 1-2, s. 179.
} 
Poczet królów i książąt polskich Jana Matejki ${ }^{37}$, Kraków w twórczości Wyspiańskiego ${ }^{38}$ oraz wydania albumowe $\mathrm{e}^{39}$.

Również Jerzy Karolak był obecny u początku tworzenia kształcenia w zakresie książki po wojnie w krakowskiej ASP, zatrudniony w szkolnictwie od 1947 roku na stanowisku profesora prowadził przedmiot projektowanie graficzne na Wydziale Grafiki ${ }^{40}$. W. Chomicz od roku 1950, wykorzystując wcześniejsze doświadczenia pedagogiczne, pracuje jako profesor w ASP w Krakowie. Objąwszy Katedrę Grafiki Książki, zajmuje się kształtowaniem umiejętności studentów w zakresie typografii i ilustracji z głównym wykorzystaniem techniki drzeworytu. Pracownia Drzeworytu, istotna dla realizacji ilustracji książkowej, w ASP w Krakowie prowadzona była do 1965 roku przez Ludwika Gardowskiego, z udziałem Franciszka Bunscha. Od roku 1960 absolwent tejże pracowni Zbigniew Jeżo podejmuje pracę asystenta $^{41}$. Po śmierci Gardowskiego w 1966 roku kierownikiem pracowni zostaje jego wieloletni współpracownik F. Bunsch.

Program nauczania Pracowni Książki i Typografii mieszczącej się w ramach Wydziału Grafiki w latach siedemdziesiątych obejmował trzyipółletni cykl nauczania specjalistycznego zakończonego dyplomem, zaczynając od drugiego semestru II roku. Na roku III i IV realizowano zadania wyposażające w wiedzę i doskonalące umiejętności. Za całość programu (podstawy reprodukcji, typografii, introligatorstwa i technik graficznych stosowanych

\footnotetext{
${ }^{37}$ Poczet królów i książąt polskich Jana Matejki, oprac. i wstęp J. Gintel, oprac. graf. W. Chomicz, Kraków 1960.

${ }^{38}$ Kraków w twórczości Wyspiańskiego, układ graf. W. Chomicz, Kraków 1959.

${ }^{39}$ Bursztynowe wybrzeże, kier. art. całości W. Chomicz, proj. graf. A. Haupt, M. Orłowska, tekst E. Męclewski, fot. J. Bułhak, Warszawa 1949; Tatry, kier. art. W. Chomicz, oprac. graf. M. Orłowska, A. Haupt, fot. T. Zwoliński, tekst Z. Schneigert, T. Zwoliński, Warszawa 1950.

40 Jerzy Mieczysław Karolak, artysta grafik (7 lipca 1907 - 1984) syn Stanisława i Franciszki z Jeżów. Po ukończeniu III Miejskiego Gimnazjum w Warszawie studiował na warszawskiej ASP w latach 1929-1936, uzyskując dyplom z grafiki użytkowej. Pracował jako zastępca kierownika graficznego w wydawnictwie Nasza Księgarnia (1934-1936) w Warszawie, wykonywał ilustracje do czasopism dziecięcych oraz szereg prac projektowych, m.in. fragmenty wystroju statków „Chrobry” i „Sobieski”, oprawy targów i wystaw prezentowanych poza krajem. Po wojnie podjął pracę pedagogiczną w ASP w Krakowie, kontynuował współpracę z wydawnictwem Nasza Księgarnia oraz Spółdzielnią Wydawniczą „Czytelnik”. W latach 1945-1947 kierownik graficzny tygodnika „Żołnierz Polski”. Zaprojektował plansze barwne Stroje ludowe w układzie graficznym H. Mortkowicz-Olczakowej, na zlecenie Polskiego Towarzystwa Ludoznawczego we Wrocławiu w 1955 r. Autor cenionych ilustracji w książkach i czasopismach dla dzieci. W latach pięćdziesiątych i sześćdziesiątych zilustrował kilkadziesiąt dziecięcych książek i podręczników, m.in. w 1957 r. Elementarz Mariana Falskiego (pismo kaligraf. A. Kwiatkowski). Brał udział w licznych wystawach ilustracji w kraju i poza jego granicami. Archiwum ASP w Krakowie, teczka osobowa; Katalogi wystaw ilustracji z lat 1955-1984.

${ }^{41}$ L. Gardowski przeszedł w 1962 r. na emeryturę, sprawował nadal funkcję kierownika pracowni i prowadził dyplomy. Zmarł w $1965 \mathrm{r}$.
} 
w projektowaniu książki) odpowiadał W. Chomicz, asystentką w pracowni była Barbara Ziembicka. Korzystano z pracowni typograficznej, liternictwa i Zakładu Technik Drukarskich (Katedra Grafiki Projektowej), kierowanego przez Janusza Benedyktowicza. Do dyspozycji studentów była pomoc składacza, opiekuna składu ręcznego Zbigniewa Tarkowskiego, laboranta Ryszarda Dyguta. Drukowanie i nadzór druku prac programowych oraz dyplomowych sprawował maszynista Henryk Hornig.

Od 1975 roku Pracownię Typografii na Wydziale Grafiki ASP obejmuje Roman Banaszewski ${ }^{42}$, w tym czasie Zbigniew Majkowski rozpoczął pracę na Wydziale Grafiki w krakowskiej ASP w Katedrze Projektowania Książki i Typografii jako asystent pod kierunkiem R. Banaszewskiego ${ }^{43}$. W 1979 roku asystentem zostaje Stanisław Jakubas, nadal pracuje Z. Jeżo. O wadze tej pracowni dla kwalifikacji projektowania książki świadczy fakt, że w latach 1959-1988 na 75 wykonanych przez studentów dyplomów w pracowni 32 dotyczyło projektu książki, absolwenci tej specjalizacji nie odegrali jednak decydującej roli, która przypadła środowisku warszawskiemu ${ }^{44}$. Od roku 1984 roku Zbigniew Majkowski kontynuuje pracę w pracowni jako adiunkt.

Działała pracowniana drukarnia zorganizowana przez Chomicza oraz pracownia introligatorska. Pracownia dawała możliwość zaznajomienia się z tradycyjnymi technikami drukarskimi. ,Jest drukarnia, w której choć raz

\footnotetext{
${ }^{42}$ Roman Banaszewski (ur. w 1932 r. w Janikowie). W latach 1954-1959 studiował w ASP w Krakowie malarstwo i grafikę. W 1959 r. uzyskał dyplom na Wydziale Grafiki w pracowni litografii u profesora Srzednickiego i w pracowni plakatu u profesora Makarewicza. Od ukończenia studiów nieprzerwanie zajmuje się grafiką warsztatową, rysunkiem i malarstwem. Rezultaty tej pracy pokazywał na wielu wystawach indywidualnych i zbiorowych w kraju i za granicą. W 1975 r. objął Pracownię Typografii, jako doświadczony pedagog z tytułem docenta. Od roku 1961 prowadził pracę pedagogiczną jako asystent na Wydziale Architektury Politechniki Krakowskiej. W roku 1964, po przewodzie I stopnia uzyskał tytuł adiunkta. W roku 1969, równolegle z pracą na Wydziale Architektury Politechniki Krakowskiej, prowadził zajęcia z podstaw komunikacji wizualnej dla studentów Wydziału Form Przemysłowych ASP. W 1987 r. otrzymał tytuł profesora, nadal kierował Pracownią Projektowania Grafiki Książki i Typografii. Kierował również Katedrą Grafiki Projektowej ASP w Krakowie. Pełnił funkcję prorektora do spraw studenckich. Prace autorstwa Banaszewskiego znajdują się w zbiorach muzealnych, galeriach oraz w kolekcjach prywatnych w kraju i za granicą, m.in. MKiS w Warszawie. W roku 2000 Roman Banaszewski wziął udział w Międzynarodowym Plenerze w San José de la Esquina w Argentynie oraz w wystawie poplenerowej w galerii Uniwersytetu w Rosario. W roku 2002 otrzymał „Złoty Laur” za mistrzostwo w sztuce za rok 2001, przyznawany przez Fundację Kultury Polskiej.

43 Zbigniew Majkowski, artysta grafik (24 lipca 1946 - 17 stycznia 2011). Studiował na Wydziale Form Przemysłowych Akademii Sztuk Pięknych w Krakowie w latach 1966-1972. Dyplom uzyskał w roku 1972 pod kierunkiem Ryszarda Otręby w Katedrze Komunikacji Wizualnej.

${ }^{44}$ Pracownia Drzeworytu ASP w Krakowie, ASP, Kraków 1973. ASP w Krakowie przyjęła w 1979 r. imię Jana Matejki.
} 
należy zrobić stronę tytułową, okładkę, czy zamakietować książkę" - wspomina absolwentka Maria Wróbel ${ }^{45}$. Kształcenie opierało się głównie na zadaniach przygotowujących do szeroko rozumianej grafiki książkowej, realizowanych w ciągu sześciu semestrów, jeden dotyczył zadań związanych z książką dla dzieci.

\section{Podsumowanie}

Profesjonalne kształcenie artystyczne przełożyło się na sukcesy polskich ilustratorów. Potwierdzają to analizy kształcenia plastycznego oraz opracowań graficznych książki dla dzieci, jak również opinie ilustratorów. O. Siemaszko podkreślała: „W Polsce ilustracją książkową zajmowali się i zajmują plastycy z gruntownym wykształceniem akademickim, a nie ludzie przypadkowi jak to ma wielokrotnie miejsce w innych krajach. Stąd jej bardzo wysoki poziom artystyczny, zapoczątkowany przed wojną" ${ }^{46}$.

Warszawska ASP po transformacji ustrojowej kontynuowała chlubne tradycje w zakresie kształtowania formy książki. Struktura współczesnego kształcenia w zakresie książki obejmuje na Wydziale Grafiki m.in. Katedrę Komunikacji Wizualnej i Katedrę Książki i Ilustracji. Znamienne są słowa J. Stannego dotyczące pracy ze studentami w Pracowni Książki i Ilustracji w warszawskiej ASP dotyczące ostatnich lat działalności pedagogicznej artysty przypadającej na przełom wieków:

Przez ostatnie kilka lat obserwuję spowolnienie emocji. Na przykład zadania związane z literaturą romantyczną wywołują sprzeciw, że to ramota, przemęczona w liceum. [...] Książka przegrywa z telewizją. Kiedy nie było masowego oglądania, studenci przynosili coś własnego, a teraz pokazują obrazki telewizyjne jak Kaczor Donald czy myszka Miki ${ }^{47}$.

Ważne zadanie spełnia Pracownia Grafiki Wydawniczej z zadaniem dyplomowania dla II-V roku, kierowana przez Lecha Majewskiego z asystenturą Justyny Czerniakowskiej ${ }^{48}$. Lech Majewski, uczeń H. Tomaszewskiego,

\footnotetext{
${ }^{45}$ Korespondencja z M. Wróbel z roku 2004.

${ }^{46}$ A. Kobylińska, Ilustrowanie to sprawa intymna..., „Kurier Polski”, 8 września 1988, nr 176.

47 Przymus szopa pracza, s. 47, 50.

${ }^{48}$ Lech Majewski (ur. 1947) wybitny grafik. profesor ASP w Warszawie, pełnił funkcje prodziekana i dziekan Wydział Grafiki. Wkłada na wielu uczelniach poza krajem. Zajmuje się rysunkiem, projektowaniem graficznym, plakatem i książką. Przewodniczący Komitetu Organizacyjnego Międzynarodowego Biennale Plakatu w Warszawie. Laureat wielu prestiżowych nagród, Brał udział w prezentacjach zbiorowych, autor wielu wystaw indywidualnych w kraju i na świecie. Zob. Lech Majewski. Vision of Design, Wydawnictwo Index, 2007. Nagrodzony w konkursie PTWK za podręcznik do nauki j. polskiego dla klasy I Litery 1989, Pisze litery 1994, Słówka dla kl. II 1994, Słówka dla kl. III 1995.Wyróżnienie na BIP Lipsk za podręcznik matematyka dla kl. I 1989.
} 
przedłuża żywotność metod pracy pedagogicznej swego mistrza, autorsko je doskonaląc. Kolejną pracownią dyplomującą jest Pracownia Projektowania Plakatu Mieczysława Wasilewskiego z asystenturą Luizy Kwiatkowskiej.

Katedrę Książki i Ilustracji tworzy Pracownia Liternictwa dla studentów I roku pod kierunkiem Andrzeja Nowaczyka z asystenturą Agnieszki Cieślikowskiej oraz dwie pracownie dyplomujące dla studentów II-V roku. Są to Pracownia Projektowania Książki Macieja Buszewicza oraz Pracownia Ilustracji Zygmunta Januszewskiego, w której asystentką jest Monika Hanulak. Pracownia Projektowania Książki Macieja Buszewicza, jednego z najbardziej znanych polskich grafików specjalizujących się w projektowaniu książek, słynnego z wyjątkowych rozwiązań ilustracyjnych i typograficznych, powstała w 1999 roku $^{49}$. Działalność pracowni zaznacza się szczególnym, rozpoznawalnym stylem. Pracownia Projektowania Książki Macieja Buszewicza specjalizuje się w doskonałości typograficznej, jej absolwenci uzyskują nagrody, są zauważani na rynku wydawniczym. G. Lange pracowała tam na stanowisku asystenta do 2002 roku i na stanowisku adiunkta do 2008 .

Pracownię Książki i Ilustracji opuszcza, przechodząc na emeryturę, Janusz Stanny, a od 2003 roku przejmuje ją Zygmunt Januszewski. Podsumowując w znamiennej rozmowie z J. Stannym miniony czas, podkreśla „Ale piękna pętla czasoprzestrzenna! Dzięki Ci za tę brawurową podróż, za pogodny dowcip i za dystans do rzeczywistości. Dzięki za wspólnie prześmiane dni i lata nauki" 50 .

\section{Bibliografia}

Akta personalne Szancera, IS PAN.

Akta personalne W. Rowida, IS PAN.

Archiwum ASP w Krakowie, teczka osobowa J. M. Karolak.

Archiwum ASP w Warszawie, teczka osobowa J. M. Szancer, sygn. KD 148.

Archiwum ASP w Warszawie, Życiorys z dn. 5 grudnia 1947 roku, Akta osobowe, K 511.

Bołdok S., J. M. Szancer, „Przegląd Artystyczny” 1966, nr 4.

Budować wrażliwość. Z Januszem Stannym rozmawia Hanna Gancarczyk, „Guliwer” 1994, $\mathrm{nr} 1$.

\footnotetext{
${ }^{49}$ Program Międzynarodowej Konferencji Europejska Sztuka Ilustracji w Warszawie, 21-22 maja 2009, druk ulotny.

${ }^{50}$ www.muzeumkarykatury.pl/wystawy/wystawy_strony/Stanny/films/stanny_film_1.html
} 
Grońska M., Stanisław Ostoja-Chrostowski 1900-1947, „Akademia Sztuk Pięknych w Warszawie. Zeszyty Naukowe" 1986, nr 2.

Iwanicka K., Ludzie polskiej książki, „Wydawca” 2002, nr 5.

Iwanicka K., Nagroda dla Janusza Stannego, „Guliwer” 2001, nr 2.

Iwanicka K., Wpływ warszawskiej Akademii Sztuk Pięknych na kształtowanie się polskiej szkoły ilustracji, „Guliwer” 1993, nr 4.

Jan Marcin Szancer (1902-1973), 100-lecie urodzin, wstęp A. Matynia, Warszawa 2002.

Janusz Stanny rozmawia z redakcja (rozmawiał J. Zielecki), „Sztuka” 1989, nr 2.

Janusz Stanny, Galeria ZPAP, maj-czerwiec, Lublin 2002.

Januszewski Z., Stuszna racja, Warszawa 2002.

Kobylińska A., Ilustrowanie to sprawa intymna..., „Kurier Polski”, 8 września 1988, nr 176.

Lech Majewski. Vision of Design, Index Book, 2007.

Olszewski A., Bonawentura Lenart, „Projekt” 1957, nr 5.

Pietrzak A., Prace graficzne profesorów studentów warszawskiej ASP w zbiorach Biblioteki Narodowej, „Biuletyn Informacyjny Biblioteki Narodowej” 2004, nr 3.

Pietrzak A., S. Ostoja-Chrostowski (1900-1947) grafika, ekslibris, rysunki i matryce graficzne ze zbiorów Biblioteki Narodowej, Warszawa 2007.

Piwocki K., Historia Akademii Sztuk Pięknych w Warszawie 1904-1964, Wrocław 1965.

Program Międzynarodowej Konferencji Europejska Sztuka Ilustracji w Warszawie, 21-22 maja 2009, druk ulotny.

Przymus szopa pracza. Z prof. Januszem Stannym rozmawia Katarzyna Kotowska, „Guliwer" 2004, nr 2.

Rey J., Nie umiem pisać. Rozmowa z O. Siemaszko, „Rzeczpospolita”, 5 lipca 1989, nr 155.

Stanny, Warszawa 2002.

Szancer J. M., Curriculum vitae, Czytelnik, Warszawa 1969.

Szancer J. M., Teatr cudów, Czytelnik, Warszawa 1972.

Wróblewska D., Janusz Stanny, „Projekt” 1968, nr 6.

Zakrzewska M., Radwan Wacław Teofil, Polski Słownik Biograficzny, t. XXX/1, 1987, z. 124. 